\title{
SEIMSIC CONDITION ASSESSMENT OF TEMPLE A CASE STUDY ON SHIVA-PARBATI TEMPLE
}

\author{
Dinesh Raj Bhattrai \\ Managing Director / Structural Engineer of Artista Engineering Consultancy (P.) Ltd Kathmandu, Nepal
}

Dinesh Rawat

M.Tech (Structural Engineer), Amity school of Engineering and Technology, Amity University, Uttar Pradesh, India

\begin{abstract}
Shiva Parvati temple is an uncommon shrine built on a four-step brick platform. It stands out particularly due to its three golden pinnacles. It was Bahadur Shah Idea to construct a hybrid temple that incorporated Newar and Rajput style on top of the pavilion built by King Laxmi Narasimha Malla who ruled in the seventeenth century. The temple has been renovated in 1998AD. The golden pinnacle of this temple is quite artistic and one of the best in the Durbar Square. It consists of three tapering spires alternating with four floral stalks on a small platform. It is unique because it departs from the traditional Newar appearance and adopts the Rajput/Mughal style. Shiva-Parvati Temple which is adorned with images of Shiva and his consort Parvati. With its "Shiva-Parvati Temple" historical importance as Monument underlying the UNESCO World Heritage Sites and One which is affected by the Gorkha Earthquake (2015). The main objective of the study is to carry out seismic condition assessment of the temple based on detail damage assessment. A set of Architectural and Structural Drawings has been prepared along with the NonDestructive Tests and Finite Element Modeling by using the Structural Analysis and Design software SAP. The temple is built with the traditional newer construction technology with load bearing walls in surkhi mortar cladding on outer face by Dachi Appa and floor and roof with timber members. This paper focuses on the visual damage assessment and detail study of the cracks in different locations of the temple. The flexible diaphragm, lack of bands and insufficient chukuls (Spikes) leads to the damage on the Temple.
\end{abstract}

Keywords- Gorkha Earthquake (2015); UNESCO World Heritage Site; Damage Assessment; Newari Traditional Construction Technology

\section{INTRODUCTION}

The earthquake that happened on April 25, 2015 with a magnitude of $7.8 \mathrm{Mw}$ and its strong aftershock on May 12 with a magnitude of $7.3 \mathrm{Mw}$ destroyed several monuments. There is a rather long list of partially to fully damaged monuments among 140 monuments damaged within Kathmandu Valley World Heritage 39 monuments were in Hanumandhoka Durbar Square. Among those 39 damaged monuments many are already resorted some are under restoration.

The Shiva Parvati temple is an uncommon shrine built on a four-step brick platform. It stands out particularly due to its three golden pinnacles. The temple was built by Regent Bahadur Shah towards the end of the eighteenth century during the rule of his nephew Rana Bahadur Shah.

Bahadur Shah (the youngest son of Prithvi Narayan Shah) was a great promoter of Nepali art and craft. It was his idea to construct a hybrid temple that incorporated Newar and Rajput style on top of the pavilion built by King Laxmi Narasimha Malla who ruled in the seventeenth century.

Out of the four brick steps, the first step is considerably wider and is often used as a stage. There are five full size doors on front side, but only the central one is functional. When open, the door reveals images of the Nava Yogini - Mangata, Pingala, Dhanya, Bhramari, Bhadrika, Ulka, Siddha, Sankata and Bikata - and Tarkeshwor Shiva lingam preserved on the ground floor. The Nava Yogini is mothers of the Nava Graha ("the male personifications of the nine planets") and is believed to be responsible for good or ill fortune. If one is going through a rough time in terms of finances, love or health, a shanti pooja of the Nava Yogini (an apotropaic ritual) is in order to turn the baneful period into a favorable one. On most days, one is likely to witness these rituals when this door to the temple is open.

A great assortment of decorative windows lines the balcony giving this abode of Shiva Parvati an exotic appeal. From the open central window of the second floor, we can see the two wooden images of Shiva and Parvati gazing out at their worshippers and admiring the scenery.

The golden pinnacle of this temple is quite artistic and one of the best in the Durbar Square. It consists of three tapering spires alternating with four floral stalks on a small platform. It is unique because it departs from the traditional Newar appearance and adopts the Rajput/Mughal style. 
Shiva-Parvati Temple which is adorned with images of Shiva and his consort Parvati. With its "Shiva-Parvati Temple" historical importance as Monument underlying the UNESCO World Heritage Sites and One which is effected by the Gorkha Earthquake (2015), It is the intend of Hanumandhoka Durbar Square Conservation Program, Basantapur, Kathmandu to hire the consulting services for the Seismic Condition Assessment of Shiva-Parvati Temple as it has limited resources and experts to do the work like that. Before it goes under either restoration or conservation program Hanumandhoka Durbar Square Conservation Program "Kathmandu Metropolitan City Office" utilizes its internal fund to know the structural system of the temple and to identify the status of the temple.

Reconstruction, renovation and Conservation of monuments as temples, shrines and monasteries across the country, damaged by the April 25, 2015 Gorkha earthquake, have been started gradually. According to the Department of Archeology, a total of 753 temples, shrines and monasteries across the country suffered damages from the earthquake. The earthquake damaged 241 temples and shrines in Kathmandu, 73 in Bhaktapur and 130 in Patan. One of them has been Assigned to us to carry out the Seismic Condition Assessment of the Shiv-Parbati Temple [World Heritage Monument] which is Two Storey richly decorate with wood carved reliefs of gods and symbols. The construction materials used for the construction are Bricks (Chimey made, Dachi Appa, Fa Appa, Nago Appa, Kasimo, etc), Stone (The carved one), Timber, Jhingati, Surkhi, Mud etc.

\section{PRoposed Algorithm}

\section{A. EVALUATION PROCEDURE OF CONDITIONAL ASSESSMENT}

The process of assessing the structural condition of an existing structure consists of assembling and systematically analyzing information and data regarding to determine the structural adequacy. A general procedure for conducting a structural assessment of an existing structure is shown in figure 1 and described therein. The procedure depends on the specific purpose of the investigation, the availability of design and construction documents, and the number of buildings encompassed in the investigation.

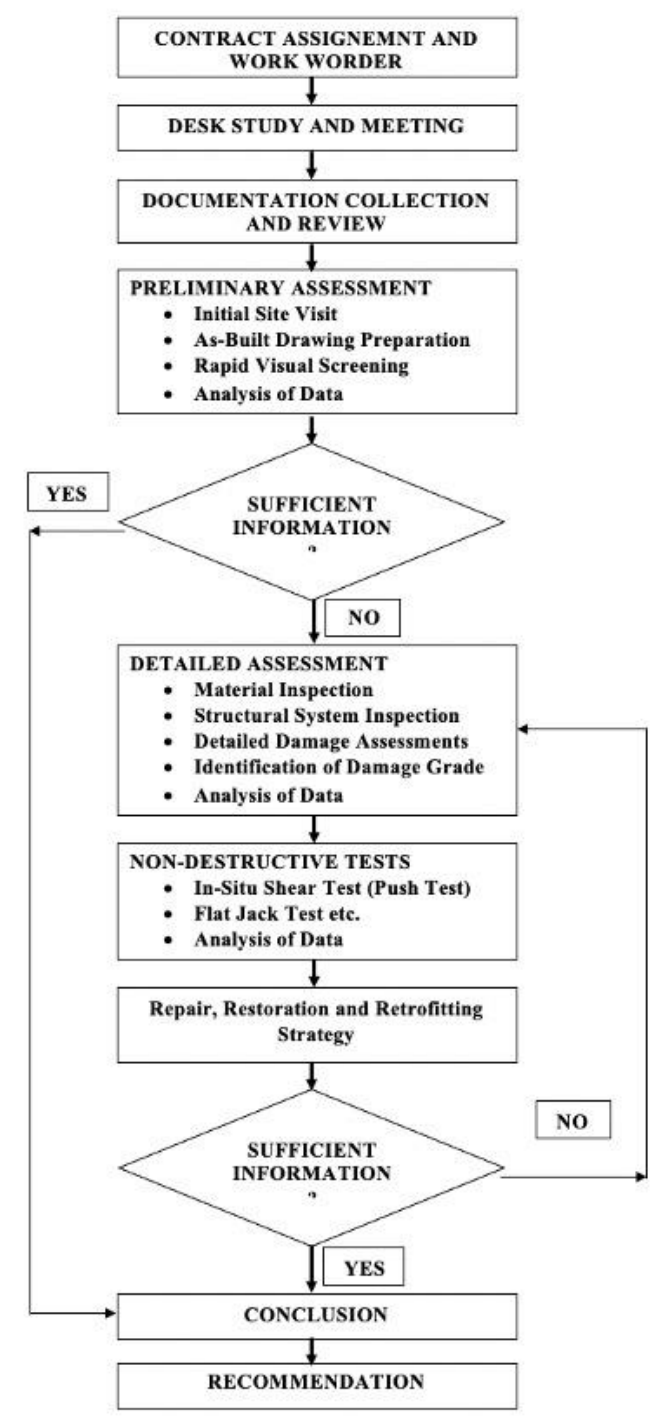

Fig. 1. Condition Assessment and Evaluation Procedure of the Structure

\section{B. DETAIL STRUCTURAL CHARACTERISTICS OF THE TEMPLE}

Shiva-Parbati Temple is a Rectangular Shaped temple located in a plain land. It is $15 \mathrm{~m}$ high with Single Tired Roof. The wall thickness varies from 1'-6" in the Ground Floor to 1'-0' in the Top Floor.

\section{B.1 Foundation}

The foundation is not exposed in the Shiva-Parbati Temple. The foundation may have a stepped footing according to the literature review and study of the similar temples. But temple has a Wide Plinth as shown in figure 2. 


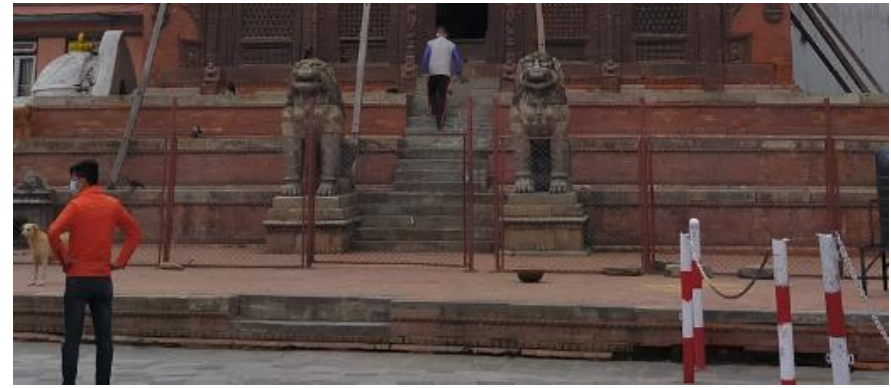

Fig. 2. Section of footing

\section{B.2 Masonry Wall}

It was observed at site that, the external brick wall is exposed of Single Layer of Dachiapa Bricks (having a thickness of 45 " thick] on all the elevation sides, ordinary brick masonry in the middle portion and Sundried brick masonry work to the inside, which can be depicted in figure 3 representing from left to right. However, the middle portion of the wall is not visible; it might be filled with brick masonry works in different bonds.
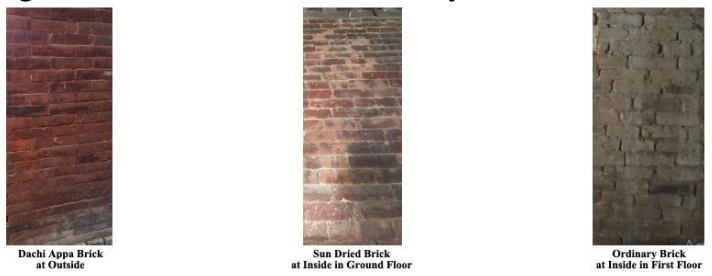

Fig. 3. Section of wall

\section{B.3 Floor}

The floor is constructed with the Wooden Joists and Timber Planks over which the Teila Bricks has been laid with Cement Mortar of thickness $12 \mathrm{~mm}$. To tie the horizontal and vertical members Wooden Chukul (Wedges) are provided for strengthening. The chukul (wedges) are fixed along the wall and in the perimeter to connect the joist with the wall throughout the Temple. The typical floor view is shown in figure 4;
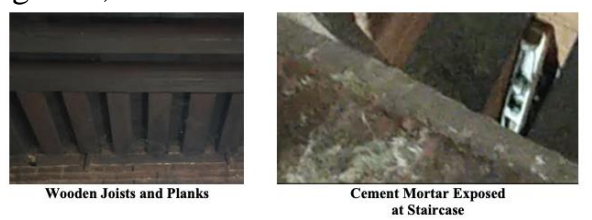

Fig. 4. Section of Flooring

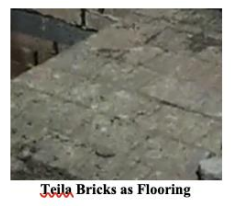

Teila Bricks as Flooring
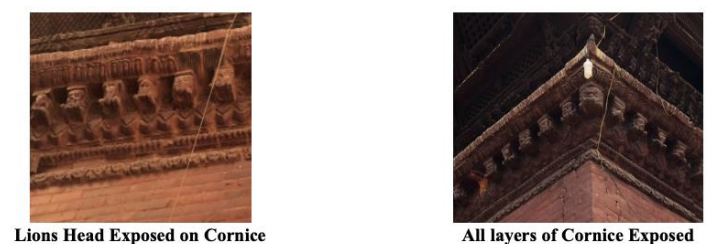

Fig. 5. Cornice Section Details at Lintel Level and Floor Level

\section{B.5 Roofs}

The roofing in the temple is of jhingati (roof tile) in the roof slopes and four tapering spires in three golden pinnacles at top most roofs. The jhingati roofing is done in different layers as shown in figure 6 below. Wood planking is placed above the rafters. Tarfelt sheets are laid above the wooden planking to protect from water seepage. The jhingati are laid on the mud. The sloped roofs are supported by the fan rafters and it is laid on the purlin and wall plate of the horizontal beam which comes from the core. The overhang of the roof is supported by the struts.
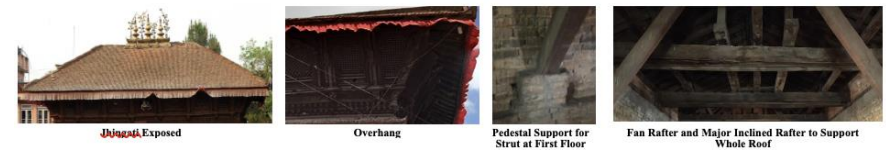

Fig. 6. Roofing Section Details

\section{RESULTS OF THE CONDITION ASSESSMENT \\ C.1 Timber}

Lack of proper connection ties and lintel bands as well as sill bands is seen in the temple. Chukul/Wedges (Wooden pegs) are seen in minimum number that connect the floors and the joists. The overhang portion is mostly affected in the Gorkha Earthquake as dislocation of the struts and eaves from its position. Also, it is observed that fan rafter, purlin and Planks are decayed due to the water leakage in the temple from the pinnacle and also the age after they exposed in the moist condition in the years.
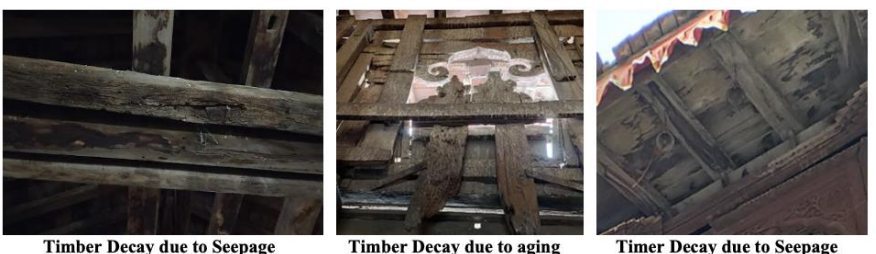

Fig. 7. Status of Timber

B.4 Cornice

Wooden cornice is put as a band along with all facades of Shiva-Parvati Temple. The cornice band consists of different layers of Kamal, Jhallar, Lion heads etc., as shown in figures below. The section of the cornice is shown in figure 5 .

\section{C.2 Masonry Walls}

The major types of damages seen is masonry walls are the shear cracks, compression cracks, vertical cracks, corner separations, delamination, short lintel band and cracks in the 


\section{International Journal of Engineering Applied Sciences and Technology, 2021 \\ Vol. 5, Issue 11, ISSN No. 2455-2143, Pages 295-298 \\ Published Online March 2021 in IJEAST (http://www.ijeast.com)}

arches. The crack patterns were compared with the crack pattern of the EMS-98.

\section{C.3 Shear Cracks}

Shear cracks in the temple are developed when the acting shear on the masonry wall exceeds the resisting shear capacity. Due to seismic behavior of Gorkha earthquake, shear cracks on the surface of the masonry wall of Siva-Parbati temple were observed in different walls of each floor. Maximum shear cracks develop in the wall is about $8^{\prime}-0^{\prime \prime}$ length and about $50 \mathrm{~mm}$ wide as shown in figure8.

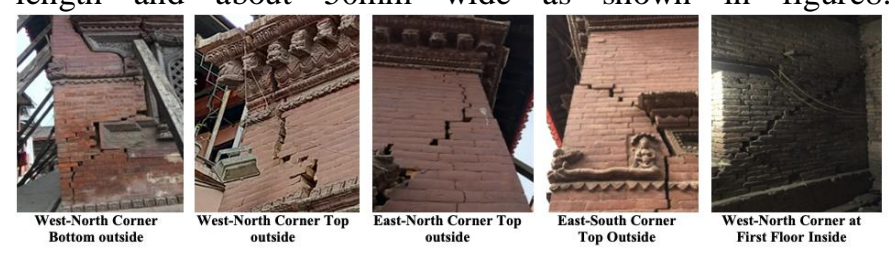

Fig. 8. Shear Cracks in different walls

\section{C.4 Short Lintel Band}

At the opening of each masonry wall, there is a wooden lintel band kept throughout the opening. The bands distribute the stress concentration on the opening to the walls. Due to the short lintel band, a surface crack from the toe of the bands during seismic activity is observed. Major damages were also observed at the west side of the main wall of the first floor due to the inadequate band at the opening. The cracks due to short lintel band are shown in figure 9 .

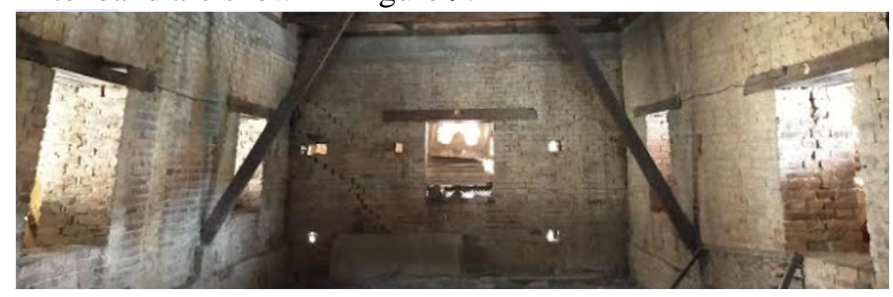

Fig. 9. Cracks observed due to Short Lintel bands

\section{RETROFITTING STRATEGY}

The temple is very old with great archeological value due to number of arts and crafts on the surfaces. Also, this temple lies inside the premises of UNESCO World Heritage Site so due consideration shall be taken before any action to be executed for the restoration program of the temple.

The most efficient way of Conservation is by providing adequate number of Chukul / Spikes / Wedges to connect the Joist and Wall which increases the lateral strength of wall, Continuous Bands throughout the periphery, Corner Stiches at the Wall Junctions \& Wooden Posts and Beams in the form of frame from the inside.

\section{CONCLUSION}

This study is focused on the condition and Vulnerability Assessment through the damage assessment and visual inspection respectively. From the view of condition assessment, various local damages-timber decay, shear cracks, vertical cracks, brick crushing, etc. were observed in the temple. Similarly, Vulnerability Assessment shows the inadequate vertical and horizontal bands; opening confinement, irregular wall system, loose timber connections, etc. in the Shiva-Parbati temple. As per the Assessment, various recommendations are proposed such as local strengthening and reconstruction. Further, this study also emphasizes the need for regular monitoring and maintenance works to be carried out for better seismic performance of the temple structure.

\section{REFERENCE}

[1] IS 13935:2009, Indian Standard for "Seismic Evaluation, Repair and Strengthening of Masonry Buildings" Guidelines.

[2] IS 13828:1993, Indian Standard for "Improving Earthquake Resistance of Low Strength Masonry Buildings" Guidelines.

[3] IS 4326:1993, Indian Standard for "Earthquake Resistant Design and Construction of Buildings" Code of Practice.

[4] IS 1905:1987, Indian Standard for "Code of Practice for Structural Use of Unreinforced Masonry".

[5] IS 2212:1991, Indian Standard for "Code of Practice of Bricks Works".

[6] Seismic Retrofitting Guidelines of Buildings in Nepal (Adobe and Masonry).

[7] Pawel Gregorczyk, A Review of Flat-Jack Testing, Universidade do Minho, Departamento de Engenharia Civil Azurém, Guimarães, Portugal

[8] Nicola Cavalagli, In Situ Shear Tests on Masonry Panels Strengthened with Fibre-Reinforced Mortar Repointing, Department of Civil and Environmental Engineering, University of Perugia, Italy

[9] Manjip Shakya, Condition Assessment of Siva-Parbati Temple After 2015 Gorkha (Nepal) Earthquake, Department of Earthquake Engineering, Khowpa Engineering College, Nepal

[10] FEMA-273, 274 and 356, Guidelines for the Seismic Rehabilitation of Buildings. 